\title{
PERBEDAAN SIKLUS TANAM BUDIDAYA RUMPUT LAUT, Kappaphycus alvarezii, TERHADAP VARIABILITAS TINGKAT SERAPAN KARBON
}

\author{
Erlania dan I Nyoman Radiarta \\ Pusat Penelitian dan Pengembangan Perikanan Budidaya \\ Jl. Ragunan 20, Pasar Minggu, Jakarta Selatan 12540 \\ E-mail:erlania_elleen@yahoo.com
}

(Naskah diterima: 21 Januari 2014; Disetujui publikasi: 28 Maret 2014)

\begin{abstract}
ABSTRAK
Rumput laut merupakan komoditas penting kelautan dan perikanan. Komoditas ini selain berperan untuk peningkatan ekonomi masyarakat pesisir juga mempunyai fungsi sebagai penyerap karbon. Penelitian ini telah dilaksanakan untuk menganalisis pengaruh perbedaan waktu siklus tanam terhadap tingkat serapan karbon oleh rumput laut, Kappaphycus alvarezii, terkait fluktuasi kondisi lingkungan perairan. Rumput laut dibudidayakan dengan sistem long line di Perairan Teluk Gerupuk selama tiga siklus tanam pada bulan Juli-November 2012. Pengamatan dan analisis sampel rumput laut dilakukan pada hari ke-0, 15, 30, dan 45 untuk masing-masing siklus tanam, dengan parameter yang dianalisis adalah laju serapan karbon, laju pertumbuhan harian, dan produktivitas budidaya. Pengukuran parameter kualitas air dilakukan secara in situ untuk mengetahui fluktuasi kondisi perairan Teluk Gerupuk. Data yang terkumpul dianalisis menggunakan metode statistik deskriptif dan inferensia. Hasil penelitian menunjukkan bahwa siklus tanam rumput laut yang berlangsung pada musim tanam berbeda memberikan pengaruh pada perbedaan pola serapan karbon oleh rumput laut hasil budidaya. Tingkat serapan karbon tertinggi dari tiap siklus diperoleh pada waktu yang sama yaitu pada periode awal budidaya, dengan nilai berturut-turut 33,13; 88,73 ; dan 18,16 ton C/ha/tahun. Budidaya yang berlangsung pada saat musim tanam produktif memberikan serapan karbon yang optimum, dan sebaliknya saat musim tanam kurang produktif serapan karbon yang dihasilkan juga minimum.
\end{abstract}

KATA KUNCl: siklus tanam, rumput laut, Kappaphycus alvarezii, serapan karbon, Teluk Gerupuk

ABSTRACT: Difference of seaweed, Kappaphycus alvarezii, cultivation cycles on variability of carbon sequestration rate. By: Erlania and I Nyoman Radiarta

Seaweeds is an important fisheries and aquaculture commodity. In addition for enhanching coastal communities economic growth, this commodity also contribute as carbon sequestration. This study was conducted to analyze the difference of seaweed, Kappaphycus alvarezii, cultivation cycles on carbon sequestration rate, that related to fluctuations of environment condition. Long-line system was used to cultivate K. alvarezii in three cycles started from July to November 2012, in Gerupuk Bay, West Nusa Tenggara. Observations and analysis of seaweed samples were conducted every 15 days: $0,15,30$, and 45 days of each cycle. The data were analyzed including carbon sequestration rate, daily growth rate, and seaweed aquaculture productivity. Measurement of water quality was conducted in situ to determine the environmental condition of Gerupuk Bay. Data were analyzed using descriptive and 
inferential statistical methods. The results showed that seaweed cultivation cycles which took place in different growing season could influenced the trend of carbon sequestered. The highest carbon sequestration rate was resulted in the same early cultivation stage of each cycles (days 0-15); the values were 33.13; 88.73; and 18.16 ton $\mathrm{C} / \mathrm{ha} /$ year, respectively. The productive period of seaweed growing season provided the optimum carbon uptake, and vise versa minimum carbon uptake during the nonproductive period.

KEYWORDS: cultivation cycle, carbon sequestration, seaweeds, Kappaphycus alvarezii, Gerupuk Bay

\section{PENDAHULUAN}

Peningkatan konsentrasi gas rumah kaca (Green House Gases/GHGs), di antaranya $\mathrm{CO}_{2}$, di atmosfir menjadi salah satu pemicu terjadinya fenomena perubahan iklim global ( $\mathrm{glo}$ bal climate change). Konsensus ilmiah secara umum menyatakan bahwa tingginya laju peningkatan emisi GHG, yang berasal dari aktivitas manusia (antropogenik) lebih dari dua abad yang lalu, terutama sejak tahun 1950, telah memberikan dampak utama perubahan iklim (Dawson \& Spannagle, 2009). Secara umum, mitigasi perubahan iklim bertujuan untuk menurunkan atau mengurangi faktor yang menjadi penyebab perubahan iklim, khususnya emisi gas-gas yang menyebabkan terjadinya pemanasan global (Houghton, 2004); antara lain karbon dioksida $\left(\mathrm{CO}_{2}\right)$. Dalam siklusnya, gas $\mathrm{CO}_{2}$ di atmosfer masuk ke laut karena adanya perbedaan antara tekanan parsial $\mathrm{CO}_{2}$ di laut dan atmosfer, gas $\mathrm{CO}_{2}$ di udara diikat oleh air laut dan digunakan oleh fitoplankton (KLH, 2007) dan tumbuhan laut lainnya. Menurut Byrne (1998), peningkatan konsentrasi $\mathrm{CO}_{2}$ akan memicu peningkatan laju fotosintesis pada tumbuhan, termasuk rumput laut, hingga mencapai tingkat titik tertentu; namun setelah melebihi titik tersebut maka laju fotosintesis cenderung konstan.

Wilayah perairan pantai mencapai $7 \%$ dari luas total area lautan (ocean) (Nellemann et al., 2009). Ekosistem perairan pantai ini memiliki peranan yang besar dalam siklus karbon. Pada perairan pantai terdapat berbagai vegetasi seperti mangrove, lamun, dan rumput laut. Vegetasi tersebut melakukan proses fotosintesis dengan cara menyerap $\mathrm{CO}_{2}$ dari lingkungan dan melepaskan oksigen $\left(\mathrm{O}_{2}\right)$ sebagai produk sampingannya. Hampir setengah dari jumlah oksigen di atmosfir berasal dari hasil fotosintesis vegetasi yang terdapat di laut (KLH, 2007). Penyerapan $\mathrm{CO}_{2}$ melalui proses fotosintesis, yang mencakup peningkatan penyimpanan karbon dalam biomassa vegetasi, di antaranya melalui pengembangan aktivitas budidaya rumput laut, merupakan langkah srategis dalam mitigasi perubahan iklim (Erlania et al., 2013; Ritschard, 1992; Chung et al., 2011).

Rumput laut merupakan salah satu vegetasi pantai yang mampu memanfaatkan $\mathrm{CO}_{2}$ melalui aktivitas fotosintesis untuk dikonversi menjadi biomassa. Saat ini, rumput laut merupakan salah satu komoditas potensial kelautan dan perikanan yang semakin berkembang terutama melalui aktivitas budidaya. Volume produksi makroalga ini secara global mengalami peningkatan dengan laju produksi tahunan $7,4 \%$ pada periode 2000 -an (FAO, 2012). Produksi rumput laut di Indonesia mencapai 3,92 juta ton pada tahun 2010 dan 4,31 juta ton pada tahun 2011 ; dengan kenaikan rata-rata 26,08\% dari tahun 2007-2011 (KKP, 2011 ). Kappaphycus alvarezii (sebelumnya dikenal sebagai Eucheuma cottonii) dan Eucheuma spp. merupakan jenis rumput laut yang mendominasi produksi rumput laut dunia pada tahun 2010 , dengan volume produksi lebih dari 5,5 juta ton (FAO, 2012). Besarnya potensi pengembangan budidaya rumput laut, menjadikan semakin besarnya peranan ekosistem laut terhadap penyerapan $\mathrm{CO}_{2}$ dari lingkungan.

Terjadinya fenomena perubahan iklim menyebabkan peningkatan rata-rata suhu global sebesar $0,76^{\circ} \mathrm{C}$ sejak tahun 1900 (Dawson \& Spannagle, 2009). Menurut Aldrian et al. (2011), setidaknya terdapat empat indikator utama terjadinya perubahan iklim di Indonesia, yaitu terjadinya perubahan suhu daratan, peningkatan curah hujan ekstrim, pergeseran musim, dan perubahan jumlah volume hujan. Berbagai dampak perubahan iklim ini akan berpengaruh secara langsung pada kondisi perairan pantai sebagai lokasi budidaya rumput laut. Salah satu aspek budidaya 
rumput laut yang terlihat sangat dipengaruhi oleh kondisi iklim yaitu pola musim tanam rumput laut. Kondisi budidaya rumput laut K. alvarezii di perairan Teluk Gerupuk, Nusa Tenggara Barat selama kurun waktu enam tahun terakhir (2007-2012) menunjukkan pola musim tanam yang cukup berfluktuasi; musim tanam rumput laut yang produktif setiap tahunnya selalu mengalami pergeseran (Radiarta et al., 2013). Kondisi ini menunjukkan bahwa produktivitas rumput laut secara tidak langsung dipengaruhi oleh kondisi perubahan iklim.

Penelitian tentang pola serapan karbon oleh rumput laut $K$. alvarezii yang dibudidayakan di Teluk Gerupuk telah dilakukan oleh Erlania et al. (2013) untuk satu siklus tanam pada tahun 2012. Berdasarkan data luas wilayah yang telah dimanfaatkan sebagai lokasi industri rumput laut nasional, yaitu mencapai 1,381 juta ha (MMAF-JICA, 2010), diproyeksikan besarnya potensi penyerapan karbon melalui budidaya rumput laut $K$. alvarezii secara nasional mencapai 28,56 juta ton karbon/tahun (Erlania et al., 2013). Faktor spesifik lokasi juga sangat menentukan besaran serapan karbon oleh rumput laut baik di alam maupun yang dihasilkan melalui proses budidaya. Beberapa penelitian telah me- nunjukkan adanya variabilitas serapan karbon dari lokasi yang berbeda (Chung et al., 2011; Muraoka, 2004; Kaladharan et al., 2009). Selain itu, secara temporal juga terdapat perbedaan karakteristik lingkungan yang spesifik dari setiap lokasi. Walaupun potensi serapan karbon secara global dan spesifik lokasi dapat diestimasi, namun masih diperlukan penelitian secara lebih spesifik terhadap perbedaan waktu dari siklus tanam terkait dengan dinamika kondisi lingkungan budidaya pada setiap siklus tanam tersebut. Penelitian ini dilakukan untuk menganalisis lebih lanjut pengaruh perbedaan siklus tanam budidaya rumput laut $K$. alvarezii terhadap serapan karbon yang terkait dengan fluktuasi kondisi lingkungan perairan.

\section{BAHAN DAN METODE}

Penelitian dilaksanakan di Perairan Teluk Gerupuk Kabupaten Lombok Tengah, Nusa Tenggara Barat (Gambar 1) pada bulan JuliNovember 2012. Menurut Radiarta et al. (2013), bulan Juli-November 2012 dapat mewakili dua musim tanam yaitu musim produktif (siklus- 1 dan siklus-2) dan musim non-produktif (siklus3). Budidaya rumput laut dilakukan dengan sistem long-line selama tiga siklus tanam berturut-turut; satu siklus adalah 45 hari. Unit

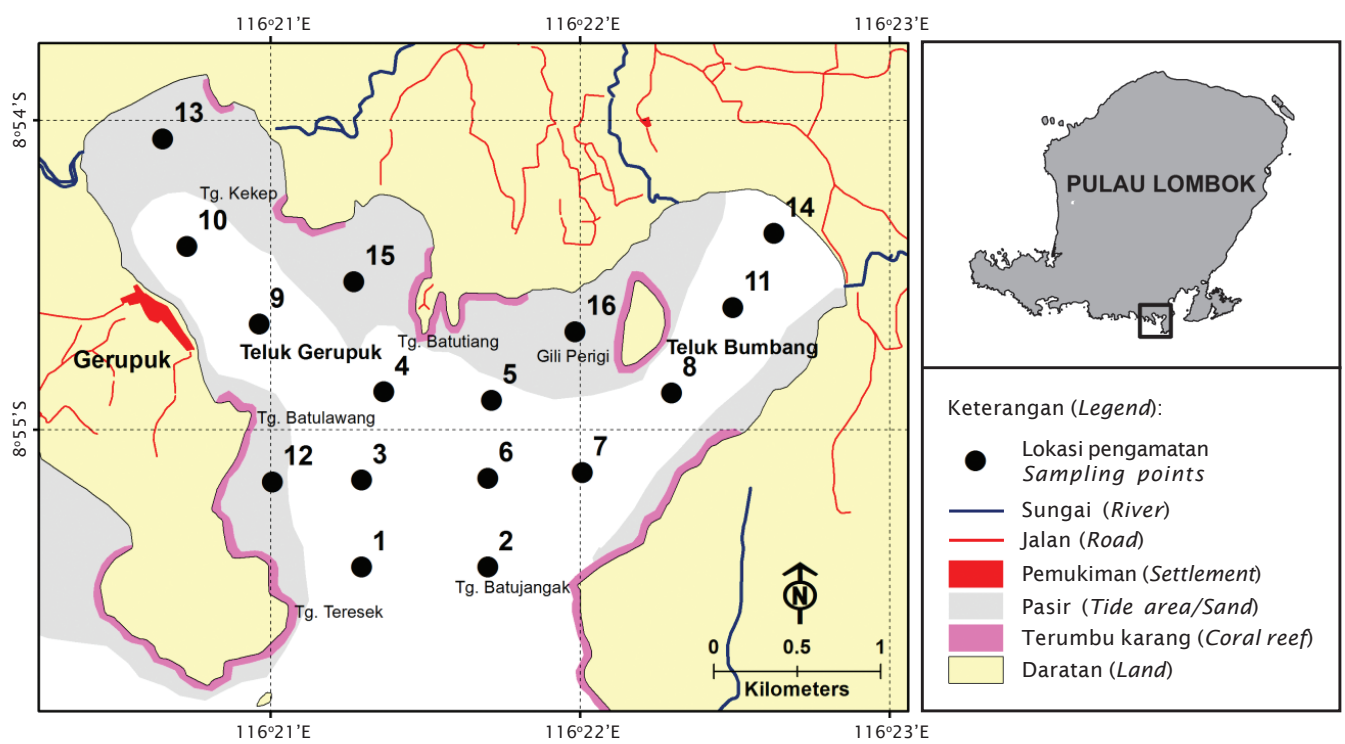

Gambar 1. Lokasi penelitian di Teluk Gerupuk, Lombok Tengah, Nusa Tenggara Barat, dan sebaran titik pengamatan kondisi lingkungan perairan

Figure 1. Research site in Gerupuk Bay, Central Lombok, West Nusa Tenggara, and distribution of water quality sampling stations 
long-line yang digunakan pada penelitian ini berukuran $50 \mathrm{~m} \times 50 \mathrm{~m}$ yang terdiri atas 25 tali ris. Satu tali ris dengan panjang $50 \mathrm{~m}$ terdiri atas 250 titik tanam. Bibit rumput laut diikatkan sepanjang tali ris dengan berat sekitar 100 g/titik tanam (SNI 7579.2:2010; BBL, 2012).

Pengamatan dan analisis sampel rumput laut dilakukan pada hari ke-0, 15, 30, dan 45 untuk setiap siklus. Pengukuran data kualitas air dilakukan secara in situ pada 16 titik pengamatan yang disebar secara proporsional di kawasan teluk (Gambar 1), dengan tujuan untuk mengetahui kondisi perairan di Teluk Gerupuk. Parameter kualitas air yang diamati adalah: suhu, salinitas, $\mathrm{pH}$, oksigen terlarut (DO), padatan terlarut (TDS), kecepatan arus, tekanan air, dan kecerahan. Selain itu, data sekunder berupa parameter meteorologi yang meliputi data curah hujan, suhu udara, dan kecepatan angin juga dikumpulkan. Data tersebut diperoleh dari Stasiun Meteorologi, Klimatologi, dan Geofisika (BMKG) Lombok yang terdekat dengan lokasi penelitian yaitu berlokasi di Bandara Internasional Lombok.

Parameter uji yang diamati adalah laju serapan karbon berdasarkan nilai kandungan karbon rumput laut (\%), total area budidaya $\left.(\mathrm{km})^{2}\right)$, standing stock $\left(\mathrm{g} / \mathrm{m}^{2}\right)$ dan rasio produksibiomassa yang dikalkulasikan mengikuti formula Muraoka (2004); laju pertumbuhan harian dan produktivitas budidaya (Lüning, 1990); serta hubungan laju serapan karbon oleh rumput laut dengan parameter lingkungan. Analisis data dilakukan secara deskriptif dan inferensia. Data parameter uji rumput laut yang dikumpulkan dianalisis menggunakan analisis regresi dan deskriptif. Untuk menganalisis hubungan parameter kualitas air dengan parameter uji rumput laut dilakukan analisis klaster dan korelasi Pearson's. Parameter meteorologi dianalisis secara deskriptif untuk melihat gambaran kondisi iklim yang dapat memengaruhi kondisi perairan dan aktivitas budidaya rumput laut.

\section{HASIL DAN BAHASAN}

\section{Pengaruh Perbedaan Musim Tanam Terhadap Tingkat Serapan Karbon}

Pemeliharaan rumput laut, K. alvarezii, dengan sistem long-line selama penelitian mengindikasikan adanya perbedaan produktivitas budidaya yang dihasilkan antar siklus. Produktivitas budidaya K. alvarezii pada siklus1 dan siklus-2 relatif tinggi dibandingkan pada siklus-3 (Gambar 2). Adanya perbedaan produktivitas tersebut disebabkan oleh dinamika dan pergeseran kondisi lingkungan antar siklus, baik lingkungan mikro pada perairan Teluk Gerupuk, maupun lingkungan makro yang mencakup kondisi meteorologi wilayah tersebut (Radiarta et al., 2013). Hal ini juga terkait dengan perbedaan waktu pelaksanaan budidaya yang berada pada dua musim tanam yang berbeda; yaitu siklus- 1 dan siklus-2 berlangsung pada musim tanam produktif yaitu pada bulan Juli hingga awal Oktober sedangkan siklus-3 berlangsung pada awal musim tanam non-produktif yaitu pada akhir bulan Oktober hingga November (Radiarta et al., 2013). Perbedaan produktivitas budidaya tersebut juga diperlihatkan dari perbedaan laju serapan karbon pada akhir masa budidaya (setelah panen). Nilai serapan karbon tersebut berturutturut dari siklus ke-1, 2, dan 3 yaitu 20,67; 43,20 ; dan 7,46 ton C/ha/tahun.

Laju pertumbuhan harian rumput laut menunjukkan pola yang relatif sama dengan laju serapan karbon; yaitu pada siklus-1 dan 2 terjadi pola penurunan dari hari ke-15 hingga hari ke-30, kemudian kembali meningkat hingga hari ke-45. Sedangkan pada siklus-3 pola kedua variabel tersebut menunjukkan penurunan dari awal budidaya hingga hari ke-45 (Gambar 2). Namun demikian, laju serapan karbon tertinggi dari tiap siklus diperoleh pada waktu yang sama yaitu pada periode awal budidaya (hari ke-0-15); dengan nilai berturutturut 33,$13 ; 88,73$; dan 18,16 ton $\mathrm{C} / \mathrm{ha}$ /tahun. Indikasi kesamaan pola dari kedua variabel ini menunjukkan bahwa karbon yang diserap oleh rumput laut dari lingkungan sebagian besar digunakan untuk pertumbuhan berupa pembentukan biomassa. Menurut Sinha et al. (2001), $\mathrm{CO}_{2}$ dapat digunakan untuk menstimulasi pertumbuhan rumput laut yang hidup pada ekosistem alami di dasar laut ataupun yang dibudidayakan di perairan pantai. Beberapa penelitian memperlihatkan bahwa di antara faktor-faktor yang memengaruhi perbedaan serapan karbon oleh rumput laut yaitu perbedaan spasial dan perbedaan ekosistem. Menurut Grimsditch \& Chung (2012), serapan karbon pada rumput laut budidaya di perairan Korea berkisar 4,28-4,53 ton C/ha/tahun; sedangkan hasil serapan karbon oleh rumput laut alam di perairan pantai Jepang berkisar 0,89-32,38 ton C/ha/tahun (Muraoka, 2004); dan di perairan pantai India 5,81-90,0 ton C/ ha/tahun (Kaladharan et al., 2009). Namun demikian, hasil penelitian ini menunjukkan 


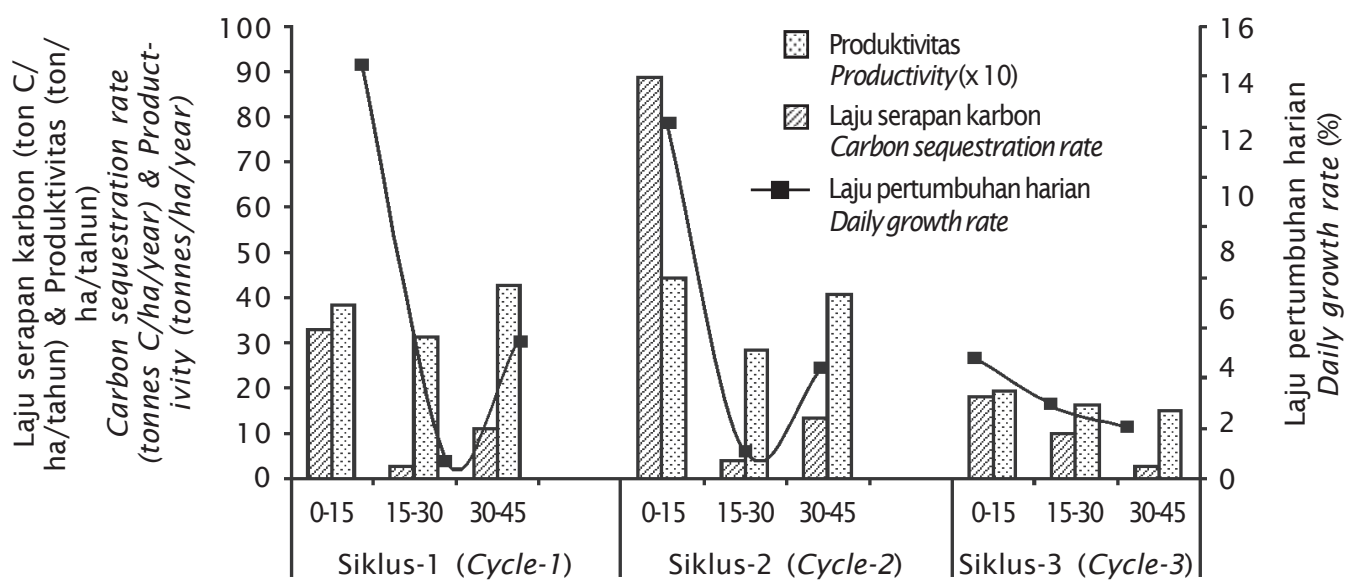

Umur budidaya (Hari)

Day of culture (Days)

Gambar 2. Pola serapan karbon dari budidaya rumput laut, $K$. alvarezii, pada tiga siklus tanam Figure 2. Trend of carbon sequestration by K. alvarezii from three cycles of cultivation

bahwa pola serapan karbon dan pertumbuhan rumput laut budidaya tidak terlepas dari pengaruh variabilitas lingkungan secara temporal, yaitu musim tanam. Sementara variabilitas antar siklus tanam itu sendiri dipengaruhi oleh adanya perbedaan kondisi lingkungan perairan pada siklus- 1 dan siklus-2 dengan kondisi perairan pada saat siklus-3 berlangsung. Dalam hal ini peran dari faktor perubahan iklim juga menjadi sangat penting dalam menentukan produktivitas budidaya rumput laut. Parameter utama dari perubahan iklim yang berdampak pada sektor kelautan dan perikanan, termasuk budidaya rumput laut di antaranya yaitu perubahan suhu muka laut, perubahan pola angin dan gelombang, perubahan pola hujan, serta perubahan frekuensi El Nino dan La Nina (Radiarta et al., 2013; Aldrian et al., 2011).

Sejak awal dimulainya budidaya jenis komersial dari kelompok eucheumatoids ini, pola musim telah menjadi perhatian sebagai faktor yang dapat berpengaruh terhadap pertumbuhannya. Kemampuan untuk mengurangi atau sepenuhnya menghilangkan efek negatif dari pola pertumbuhan musiman sehingga kualitas karaginan dan laju pertumbuhan sepanjang tahun dapat dipertahankan pada tingkat yang tinggi akan menjadi suatu kelebihan (Ask \& Azanza, 2002). Beberapa penelitian telah dilakukan terkait pengaruh dari berbagai variabel lingkungan terhadap pola pertumbuhan musiman dari K. alvarezi, dan menunjukkan hasil yang berbeda-beda; yaitu pada umumnya beberapa variabel lingkungan yang berbeda secara tunggal dapat menjadi faktor utama yang memengaruhi pertumbuhan musiman K. alvarezii pada waktu dan lokasi yang berbeda (Villanueva et al., 2011 ; Marquardt et al., 2009; Munõz et al., 2004; Davison, 1991).

Perbedaan pola hubungan antara serapan karbon oleh $K$. alvarezii dengan umur budidaya juga dapat terlihat antara siklus- 1 dan siklus-2 dengan siklus-3. Untuk dua siklus pertama yang memiliki produktivitas yang relatif tinggi (Gambar 2), pola hubungan serapan karbon dengan umur budidaya mengikuti model regresi polinomial, dengan nilai $\mathrm{R}^{2}$ berturut-turut 0,88 dan 0,77 (Gambar 3). Model hubungan pada kedua siklus ini menggambarkan bahwa $K$. alvarezii mempunyai kecenderungan pertumbuhan yang tinggi pada awal penanaman, kemudian menurun, dan kembali meningkat pada umur 45 hari. Diduga model pertumbuhan 'naik-turun-naik' (polinomial) inilah yang menjadi model pertumbuhan $K$. alvarezii secara alamiah selama 45 hari pada kondisi optimum. Hal ini sesuai dengan hasil penelitian Villanueva et al. (2011) bahwa K. alvarezii yang dibudidayakan memiliki indeks optimisasi yang tinggi pada tiga minggu pertama, selanjutnya menurun pada minggu ke-4 dan 5 , kemudian kembali meningkat pada minggu ke- 6 (hari ke45 pemeliharaan). Dalam hal ini semakin tinggi indeks optimisasi menunjukkan semakin besarnya biomassa optimum yang dapat dihasilkan. 
Siklus-3 yang memiliki produktivitas budidaya yang relatif lebih rendah dibandingkan dua siklus pertama, menunjukkan kecenderungan penurunan laju serapan karbon dan laju pertumbuhan harian (Gambar 2 dan 3) dari awal hingga akhir budidaya pada hari ke-45. Hubungan serapan karbon dengan umur budidaya pada siklus-3 mengikuti model regresi eksponensial dengan nilai $R^{2} \quad 0,88$ (Gambar 3). Model ini memperlihatkan bahwa siklus ke-3 dari budidaya K. alvarezii ini berada pada kondisi lingkungan yang kurang optimal, peningkatan kembali laju pertumbuhan dan serapan karbon belum terjadi hingga hari ke-45. Dengan kondisi lingkungan seperti ini diduga peningkatannya akan terjadi di atas umur 45 hari. Model pertumbuhan ini menunjukkan kemungkinan bahwa pada saat pertumbuhan kuantitatif berupa pertambahan biomassa rendah, maka penyerapan nutrien dan karbon dari lingkungan cenderung dimanfaatkan untuk pertumbuhan yang bersifat kualitatif berupa pembentukan senyawa fikokoloid, pigmen, dan senyawa aktif lainnya. Hal ini juga diperlihatkan pada hasil penelitian Erlania et al. (2013) yang menunjukkan bahwa kandungan pigmen dan karbohidrat pada $K$. alvarezii dan Gracilaria gigas memiliki pola yang polanya merupakan kebalikan dari pola laju pertumbuhan dan laju penyerapan karbon. Hasil penelitian Villanueva et al. (2011) terhadap K. alvarezii budidaya juga menunjukkan hal yang sama, yaitu pada saat indeks optimisasi tinggi (produksi biomassa tinggi) yaitu minggu ke-3 dan 6 , persentase karaginan yang dihasilkan lebih rendah daripada periode di mana indeks optimisasi rendah. Hal ini menunjukkan bahwa pada siklus hidupnya terdapat periode di mana pertumbuhan rumput laut cenderung bersifat kuantitatif berupa pembentukan biomassa, dan periode pertumbuhan kualitatif berupa pembentukan senyawa fikokoloid, yaitu senyawa karbohidrat sebagai produk akhir dari fiksasi $\mathrm{CO}_{2}$ dalam proses fotosintesis. Handayani (2011) menyatakan bahwa kandungan karbohidrat yang terdapat pada rumput laut sebagian besar merupakan senyawa fikokoloid; pada $K$. alvarezii berupa karaginan. Hal ini juga didukung oleh pernyataan Diniz et al. (2011) dan Chakraborty \& Bhattacharya (2012), bahwa kandungan substansi yang paling besar jumlahnya dalam rumput laut pada umumnya adalah karbohidrat.

Rumput laut merupakan salah satu vegetasi perairan pantai yang dapat berperan sebagai penyerap karbon yang sangat baik. Budidaya rumput laut sangat potensial untuk dikembangkan, karena memiliki beberapa nilai tambah dibandingkan dengan budidaya komoditas perikanan lainnya. Teknologi yang digunakan dalam budidaya rumput tergolong sederhana, tidak membutuhkan biaya produksi yang tinggi (seperti biaya pakan pada budidaya ikan), waktu pemeliharaan yang relatif singkat, serta kegiatan budidaya yang bersifat ramah lingkungan. Terdapatnya perbedaan pola penyerapan karbon oleh rumput laut, selain dipengaruhi oleh umur budidaya, juga dipengaruhi oleh perbedaan siklus tanam yang disebabkan karena adanya dinamika kualitas air sehingga menyebabkan perbedaan kondisi lingkungan. Dengan demikian, manajemen budidaya rumput laut menjadi penting dilakukan mengingat pentingnya peranan budidaya rumput laut dalam penyerapan karbon sebagai salah satu bentuk tindakan mitigasi perubahan iklim dari sub sektor perikanan budidaya.

\section{Faktor Lingkungan Perairan}

Adanya indikasi pengaruh perbedaan siklus tanam terhadap pola laju serapan karbon oleh rumput laut, $K$. alvarezii, antara lain dipengaruhi oleh dinamika kondisi lingkungan pada setiap siklus; baik kualitas perairan yang menjadi lokasi budidaya rumput laut, maupun pengaruh tidak langsung dari parameter meteorologi di wilayah yang mencakup lokasi budidaya tersebut (Radiarta et al., 2013). Menurut Dawes (1981) dan Raikar et al. (2001), terdapat berbagai parameter kualitas air yang sangat berpengaruh terhadap pertumbuhan rumput laut, namun beberapa parameter utama yang paling berpengaruh nyata terhadap laju fotosintesis rumput laut adalah: suhu, salinitas, intensitas cahaya, dan kondisi kekeringan akibat pengaruh pasang-surut. Pada penelitian ini faktor kekeringan tidak diperhitungkan karena budidaya dilakukan dengan sistem long-line, sehingga tidak mendapat pengaruh dari kondisi pasang surut air laut.

Analisis klaster dilakukan untuk mengetahui parameter kualitas air yang dominan memengaruhi pola serapan karbon pada setiap siklus tanam. Berdasarkan hasil analisis diperoleh dua klaster yang menggambarkan pengaruh parameter kualitas air terhadap pola serapan karbon pada ketiga siklus tanam (Gambar 4). Klaster 1 memperlihatkan bahwa laju serapan karbon pada ketiga siklus tanam 

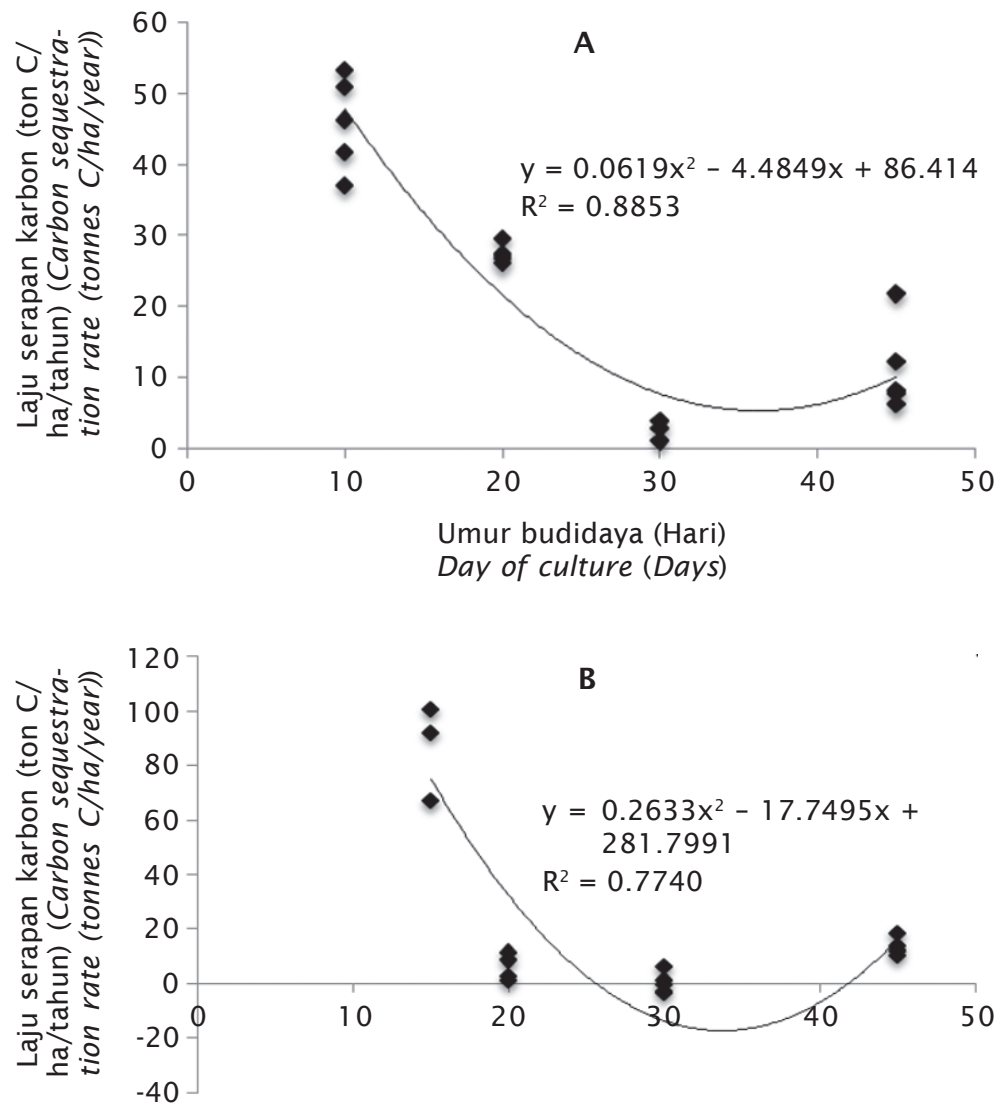

Umur budidaya (Hari)

Day of culture (Days)

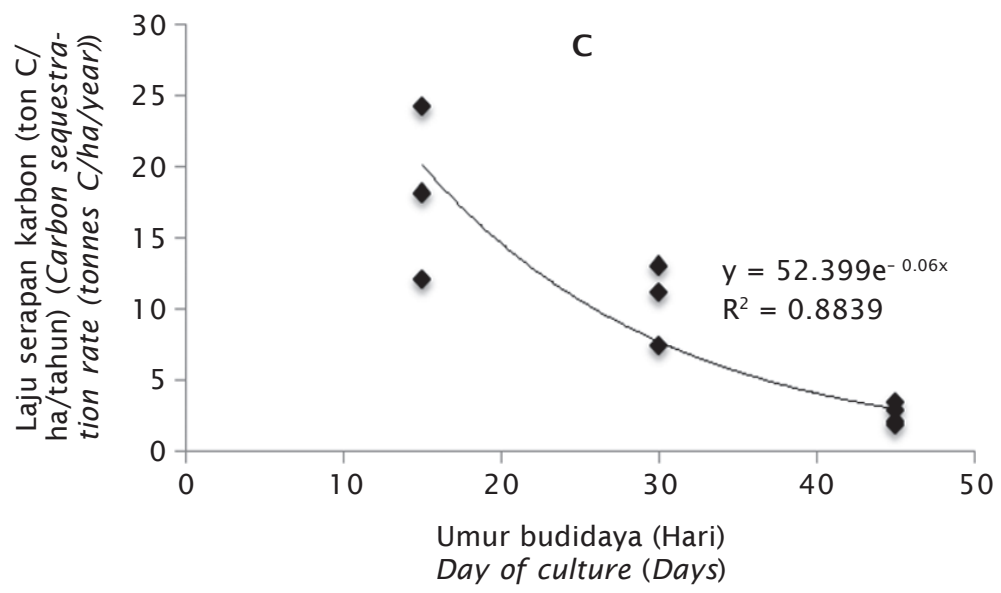

Gambar 3. Model hubungan laju serapan karbon dengan umur budidaya rumput laut $K$. alvarezii pada tiga siklus tanam: (A) siklus-1, (B) siklus-2, (C) siklus-3

Figure 3. Relationship model of carbon sequestration rate by $\mathrm{K}$. alvarezii with day of culture from three cycle of cultivation: (A) cycle-1, (B) cycle-2, (C) cycle-3 
Dendogram: Complete linkage, correlation coefficient distance

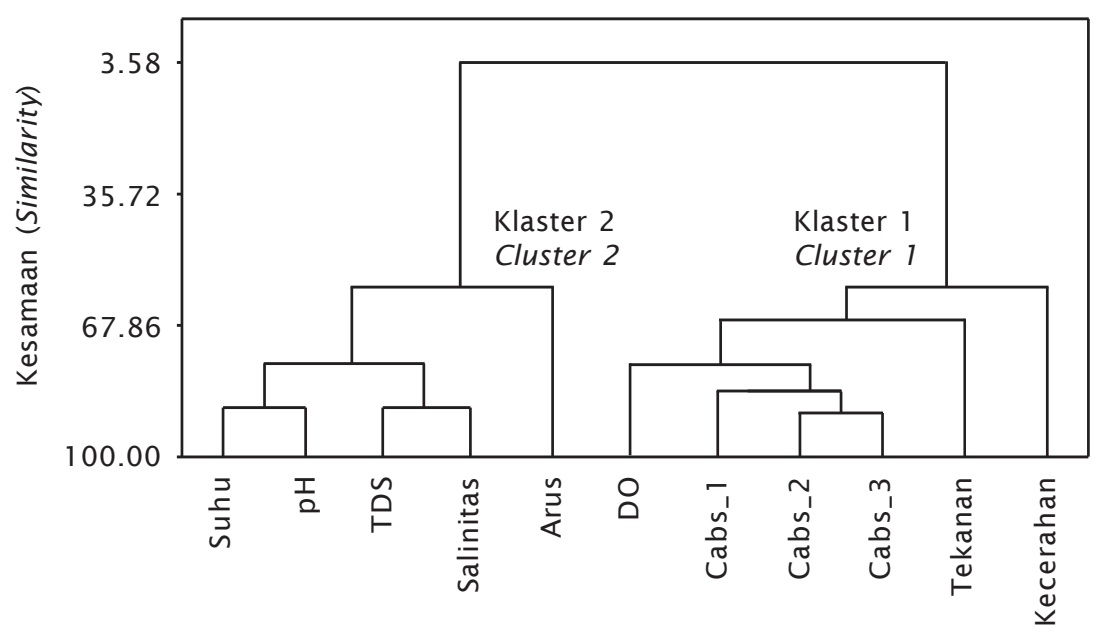

Variabel (Variables)

Gambar 4. Hasil analisis klaster dari parameter serapan karbon dan kualitas perairan

Figure 4. Cluster analysis result of carbon sequestration and water quality parameters

secara langsung berkorelasi dengan konsentrasi oksigen terlarut; selanjutnya dipengaruhi juga oleh tekanan air dan kecerahan perairan dengan similaritas inter-variabel 65,45\%. Dengan demikian dapat terlihat bahwa pada setiap siklus tanam, parameter kualitas perairan yang memberikan pengaruh paling dominan terhadap kemampuan rumput laut dalam menyerap karbon adalah tekanan air dan kecerahan perairan; sedangkan kedekatan hubungan antara laju serapan karbon dengan konsentrasi oksigen terlarut terkait dengan penyerapan karbon dalam bentuk $\mathrm{CO}_{2}$ yang digunakan oleh rumput laut dalam proses fotosintesis dan menghasilkan produk sampingan berupa $\mathrm{O}_{2}$. Besarnya pengaruh dari dinamika parameter kualitas air terhadap laju serapan karbon pada ketiga siklus tanam rumput laut tersebut terlihat dari besarnya koefisien korelasi yang ditunjukkan pada Tabel 1. Konsentrasi oksigen terlarut, tekanan, dan kecerahan perairan memiliki korelasi positif dengan laju serapan karbon oleh rumput laut pada ketiga siklus tanam; DO dan tekanan air memiliki koefisien korelasi yang besar $(>0,5)$ dengan laju serapan karbon.

Berdasarkan kedua metode analisis di atas, ditunjukkan bahwa perbedaan kemampuan rumput laut dalam menyerap karbon pada ketiga siklus tanam berhubungan erat dengan konsentrasi oksigen terlarut (Gambar 4, Tabel 1). Sedangkan menurut Dawes (1981), konsentrasi oksigen pada air laut sendiri dipengaruhi oleh suhu air, tekanan parsial, salinitas, serta adanya aktivitas biologis. Oksigen terlarut pada air laut berasal dari proses difusi dari atmosfir dan hasil sampingan proses fotosintesis pada tumbuhan, dalam hal ini termasuk rumput laut.

Tekanan air memberikan pengaruh terhadap pertumbuhan rumput laut. Sebagaimana tanaman darat yang laju pertumbuhannya dipengaruhi oleh tekanan atmosfir (Turtenwald, 2013), demikian juga tekanan air memengaruhi laju pertumbuhan rumput laut. Menurut Turtenwald (2013), jika tekanan menurun maka tanaman tetap akan tumbuh namun kecepatan tumbuhnya tidak secepat pada saat kondisi tekanan optimal; dan jika tekanan terlalu rendah tanaman tidak dapat bertahan karena terganggunya proses pertukaran gas. Pada rumput laut proses pertukaran gas utama yang akan terpengaruh akibat terjadinya perubahan tekanan air yaitu pertukaran antara $\mathrm{CO}_{2}$ dengan $\mathrm{O}_{2}$. Selain itu, tekanan juga akan memengaruhi proses penyerapan nutrien terlarut oleh rumput laut yang di dalam air berada dalam bentuk ion. 
Kecerahan perairan terkait besarnya intensitas cahaya yang dapat diserap oleh rumput laut sebagai sumber energi dalam proses fotosintesis. Korelasi positif antara kecerahan perairan dengan laju serapan karbon pada ketiga siklus tanam menunjukkan laju serapan karbon semakin meningkat jika intensitas cahaya yang diterima juga semakin besar, karena semakin banyak energi cahaya yang dapat diserap oleh pigmen fotosintesis. Alga akan menunjukkan perbedaan respons fotosintetik terhadap intensitas cahaya berdasarkan populasi, musim, dan morfologinya (Dawes, 1981). Menurut Lüning (1990), pada alga ditemukan bahwa spektrum cahaya merah mendukung terjadinya akumulasi karbohidrat, sedangkan spektrum cahaya biru memicu peningkatan sintesis protein, respirasi, dan aktivasi enzim. Rumput laut, sebagaimana tumbuhan darat dan fitoplankton, memiliki kemampuan adaptasi terhadap perubahan intensitas cahaya dengan penyesuaian kandungan pigmen dan aktivitas fotosintesis, yang dikenal dengan photoacclimation (Lüning, 1990).

Pada klaster 2 dengan similaritas intervariabel $79,39 \%$ terdapat parameter suhu dan $\mathrm{pH}$, serta salinitas dan TDS yang memiliki kedekatan hubungan saling memengaruhi antar parameter tersebut. Parameter-parameter tersebut dipengaruhi juga oleh kecepatan arus pada klaster 2 , dengan similaritas $58,92 \%$. Seluruh parameter pada klaster 2 memiliki hubungan secara tidak langsung dengan laju serapan karbon pada ketiga siklus tanam yang berada pada klaster 1. Berdasarkan hasil analisis korelasi; parameter suhu, $\mathrm{pH}$, TDS, salinitas, dan kecepatan arus berkorelasi negatif dengan laju serapan karbon, dengan nilai korelasi lebih dari 0,5; kecuali kecepatan arus yang nilai korelasinya rendah yaitu 0,04-0,16 $(<0,5)$ (Tabel 1$)$.

Kecepatan arus sangat berperan pada pertumbuhan rumput laut. Pergerakan air membantu membersihkan tanaman, menghadirkan nutrisi baru, menyingkirkan sisa-sisa metabolisme, dan gaya hidroliknya dapat merangsang pertumbuhan; aliran air yang deras dapat meningkatkan proses difusi dari tanaman ke air atau sebaliknya (Neish, 2005). Menurut Lüning (1990), salah satu efek yang menguntungkan dari pergerakan air bagi rumput laut adalah untuk mengurangi lapisan pembatas (boundary layer) yang dapat mengurangi atau menghambat difusi gas dan ion-ion di perairan; boundary layer merupakan lapisan di mana terjadinya pergerakan cairan yang lambat sehingga substansi yang harus didifusikan juga bergerak lambat, sedangkan laju transportasi substansi bergantung dari ketebalan lapisan tersebut. Stewart \& Carpenter (2003) menyatakan bahwa laju fotosintesis pada makroalga dipengaruhi oleh adanya arus atau pergerakan air; di mana pergerakan air merupakan faktor utama yang memengaruhi variabilitas morfologi dan sifat plasticity

Tabel 1. Koefisien korelasi antara laju serapan karbon pada tiga siklus tanam dengan parameter kualitas perairan

Table 1. Correlation coefficients between carbon sequestration rate in three cultivation cycles with water quality parameters

\begin{tabular}{lccc}
\hline $\begin{array}{c}\text { Serapan karbon } \\
\text { Carbon sequestration }\end{array}$ & $\begin{array}{c}\text { Siklus-1 } \\
\text { Cycle-1 }\end{array}$ & $\begin{array}{c}\text { Siklus-2 } \\
\text { Cycle-2 }\end{array}$ & $\begin{array}{c}\text { Siklus-3 } \\
\text { Cycle-3 }\end{array}$ \\
\hline $\mathrm{pH}$ & $\mathbf{- 0 . 6 9 6}$ & $\mathbf{- 0 . 7 9 3 3}$ & $-\mathbf{0 . 8 0 1 2}$ \\
Suhu (Temperature) & $-\mathbf{0 . 7 6 4 4}$ & $-\mathbf{0 . 7 7 5 5}$ & $-\mathbf{0 . 7 2 5 4}$ \\
DO (Dissolved oxygen) & $\mathbf{0 . 7 6 5 2}$ & $\mathbf{0 . 6 7 5 9}$ & $\mathbf{0 . 6 8 4}$ \\
TDS (Total dissolved solids) & $-\mathbf{0 . 7 3 1 7}$ & $-\mathbf{0 . 7 7 8 3}$ & $\mathbf{- 0 . 5 8 6 6}$ \\
Tekanan air (Water pressure) & $\mathbf{0 . 5 8 8 9}$ & $\mathbf{0 . 5 9 9 8}$ & $\mathbf{0 . 5 6 8 5}$ \\
Kecerahan (Transparency) & 0.4423 & 0.3089 & 0.3311 \\
Salinitas (Salinity) & $-\mathbf{0 . 7 1 6 3}$ & $-\mathbf{0 . 6 7 6 1}$ & $-\mathbf{0 . 6 0 4 5}$ \\
Kecepatan arus (Current velocity) & -0.039 & -0.159 & -0.069 \\
\hline
\end{tabular}

Keterangan (Note):

Angka yang dicetak tebal menunjukkan nilai korelasi yang tinggi $(>0,5)$ (Bold number indicate highly correlation value (>0.5)) 
(keliatan/kekenyalan) dari talus. Menurut Sulistijo \& Nontji (1995); Mubarak et al. (1990); dan Tiensongrusmee (1986), kecepatan arus yang relatif sesuai untuk budidaya rumput laut berkisar 20-50 cm/detik. Menurut Lüning (1990), salah satu spesies makroalga menunjukkan peningkatan laju penyerapan nitrat hingga 500\% dan laju fotosintesis hingga 300\% dengan peningkatan kecepatan arus dari 0 $\mathrm{cm} /$ detik menjadi $40 \mathrm{~cm} /$ detik.

Suhu merupakan salah satu parameter penentu yang ikut memengaruhi dinamika parameter kualitas air lainnya. Berdasarkan hasil analisis data, terlihat bahwa suhu air memiliki korelasi negatif dengan laju serapan karbon pada ketiga siklus tanam (Tabel 1). Menurut Byrne (1998) dan Dawes (1981), suhu air berpengaruh terhadap laju aktivitas enzim yang berperan dalam proses fotosintesis, sehingga laju fotosintesis dapat meningkat hingga level tertentu. Akan tetapi, peningkatan suhu melebihi batas tertentu akan menyebabkan terjadinya denaturasi enzim, sehingga peningkatan suhu akan menyebabkan terjadinya penurunan aktivitas enzim, dan menyebabkan penurunan laju fotosintesis. Terjadinya dinamika suhu air laut, akan berpengaruh juga pada $\mathrm{pH}$, salinitas, dan konsentrasi bahan terlarut yang diwakili oleh parameter TDS (total dissolved solids). Kandungan bahan terlarut dalam air laut merupakan sumber nutrien bagi pertumbuhan rumput laut. Korelasi negatif antara TDS dengan laju serapan karbon pada ketiga siklus tanam mengindikasikan bahwa semakin tinggi laju serapan karbon, maka aktivitas fotosintesis juga meningkat sehingga ketersediaan bahan terlarut berupa nutrien di perairan menurun karena dimanfaatkan oleh rumput laut.

Tabel 1 memperlihatkan bahwa kecepatan arus memiliki nilai korelasi yang rendah dengan laju serapan karbon oleh rumput laut. Hal ini terkait dengan kondisi lokasi budidaya yang terletak pada perairan teluk yang menyebabkan peranan arus menjadi tidak terlalu dominan. Namun kecepatan arus memengaruhi sebaran dari parameter kualitas air lainnya pada perairan (Gambar 4). Korelasi kecepatan arus dengan laju serapan karbon yang negatif dengan nilai yang sangat rendah, yaitu antara 0,04-0,16 mengindikasikan bahwa kecepatan arus tidak sepenuhnya berkorelasi negatif dengan serapan karbon. Kecepatan arus pada kisaran tertentu memberikan pengaruh positif terhadap performa rumput laut, namun di luar kisaran tersebut akan memberikan pengaruh yang negatif (Lüning, 1990). Pergerakan air yang terlalu kuat dapat menyebabkan patahnya talus dan nutrien terbawa arus sehingga menurunkan ketersediaan nutrien di lingkungan yang dibutuhkan untuk pertumbuhan rumput laut.

Salinitas perairan memengaruhi proses osmoregulasi pada rumput laut. Menurut Dawes (1981), terdapat berbagai mekanisme toleransi struktur dan fisiologi pada alga terhadap perubahan salinitas. Menurut Lüning (1990), organisme laut terekspos pada tekanan osmotik $2 \mathrm{MPa}$ (20 bar) terkait kondisi lingkungan dengan salinitas $30 \%$. Peningkatan atau penurunan salinitas secara tiba-tiba mengakibatkan terjadinya aliran air mengikuti gradien osmotik, serta menyebabkan tekanan turgor berubah-ubah yang dapat membahayakan alga; karena stabilitas, bentuk, dan pertumbuhan alga bergantung pada tekanan turgor yang konstan. Untuk menjaga tekanan turgor selnya. Alga harus mengembangkan mekanisme adaptasinya untuk menjaga agar tekanan osmotik di dalam selnya sedikit lebih tinggi daripada lingkungannya. Alga mengembalikan kondisi tekanan turgornya melalui pengaturan osmotik atau dikenal dengan osmoacclimation.

Berdasarkan kedua metode analisis di atas, juga dapat diinterpretasikan bahwa pengaruh beberapa parameter kualitas air secara bersama-sama menghasilkan respons penyerapan karbon yang berbeda pada siklus tanam rumput laut, $K$. alvarezii, yang berbeda di perairan Teluk Gerupuk. Kombinasi kondisi parameter kualitas air yang relatif optimal untuk budidaya rumput laut diperoleh pada siklus- 1 dan siklus2 , sedangkan pada siklus-3 memperlihatkan kualitas perairan yang relatif menurun bagi kesesuaian budidaya rumput laut yang diperlihatkan dengan rendahnya produktivitas budidaya, serta pola laju serapan karbon dan laju pertumbuhan harian yang cenderung terus menurun.

\section{Faktor Iklim}

Data meteorologi yang diperoleh dari BMKG terdekat yaitu mulai bulan Januari sampai Desember 2012 ditampilkan pada Gambar 5 . Berdasarkan pola dari beberapa parameter meteorologi, secara parsial dapat terlihat bahwa pada periode Juli-Agustus rata-rata suhu udara relatif lebih rendah dibandingkan dengan periode Januari-Juni dan September- 
Desember. Kisaran suhu udara harian pada periode Juli-Agustus tersebut yaitu $22,3^{\circ} \mathrm{C}$ $26,2^{\circ} \mathrm{C}$ atau rata-rata $23,9^{\circ} \mathrm{C}$. Penurunan kisaran suhu udara mulai terlihat pada awal bulan Mei, dan diperkirakan berdampak pada terjadinya penurunan suhu air laut. Selanjutnya pada akhir bulan Agustus hingga Desember suhu udara mengalami peningkatan dengan rata-rata suhu $25,87^{\circ} \mathrm{C}$. Kisaran suhu air laut selama penelitian yaitu $25,1^{\circ} \mathrm{C}-29,1^{\circ} \mathrm{C}$.
Radiarta et al. (2013) melaporkan bahwa pada lokasi tersebut kecenderungan terjadinya penurunan suhu udara (suhu udara minimum) terjadi sekitar Bulan Juni-Agustus setiap tahun pengamatan, yaitu dari tahun 2005-2012. Namun data tahun 2012 menunjukkan bahwa kisaran suhu udara hingga pertengahan bulan September masih relatif rendah, selanjutnya baru mulai meningkat pada akhir September (Gambar 5).
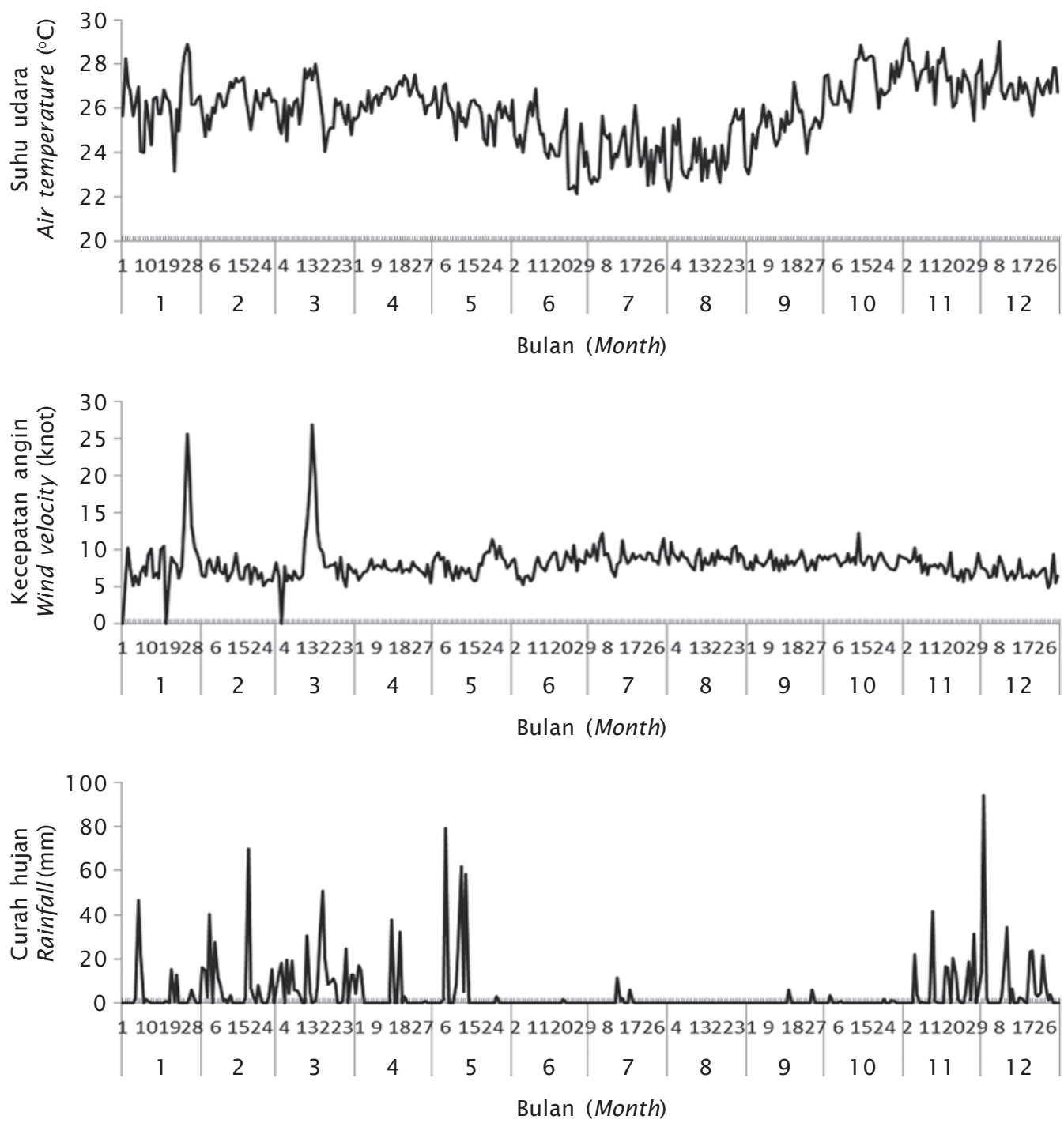

Gambar 5. Pola parameter meteorologi (suhu udara, kecepatan angin, dan curah hujan) tahun 2012 di lokasi penelitian

Figure 5. Trend of meteorology parameters (air temperature, wind velocity, and rainfall) during 2012 in the study site 
Kecepatan angin pada bulan April-Desember relatif stabil yaitu berkisar antara 5-12 knot. Kondisi ini dapat memberikan dampak positif terhadap stabilitas kondisi arus permukaan laut, yaitu berkisar antara 0,1-0,2 m/ detik. Adanya pergerakan air sangat penting bagi rumput laut terkait laju pertumbuhannya. Menurut Lüning (1990), salah satu spesies makroalga menunjukkan peningkatan laju penyerapan nitrat hingga $500 \%$ dan laju fotosintesis hingga 300\% dengan peningkatan kecepatan arus dari $0 \mathrm{~cm} /$ detik menjadi $4 \mathrm{~cm} /$ detik. Stewart \& Carpenter (2003) juga menyatakan bahwa laju fotosintesis pada makroalga dipengaruhi oleh adanya arus atau pergerakan air; pergerakan air merupakan faktor utama yang memengaruhi variabilitas morfologi dan sifat plasticity (keliatan/kekenyalan) dari talus.

Curah hujan pada bulan Juni-Oktober sangat rendah, yaitu berkisar antara $71 \mathrm{~mm}$ hingga $12 \mathrm{~mm}$; atau relatif tidak ada hujan dan cuaca cerah, sehingga intensitas cahaya matahari relatif tinggi di atas permukaan laut, yaitu 56-80.400 lux pada kisaran waktu pukul 06.00-15.00 WITA. Selain itu, rendahnya curah hujan tersebut juga menyebabkan salinitas air laut relatif tinggi dan tidak menunjukkan fluktuasi yang signifikan, yaitu berkisaran antara 34,07-35,78 ppt; rata-rata 35,12 ppt. Stabilitas kondisi perairan pada kisaran waktu tersebut mendukung produktivitas budidaya rumput laut yang juga relatif baik, yaitu untuk siklus-1 dan 2 (Gambar 2). Kondisi ini sesuai dengan hasil studi Radiarta et al. (2013) bahwa curah hujan yang rendah terjadi sekitar bulan Juni-Oktober setiap tahunnya kecuali tahun 2010; dan pada saat curah hujan minimum, suhu udara umumnya menunjukkan nilai terendah. Kondisi ini sangat mendukung untuk aktivitas budidaya rumput laut yang berkembang di Teluk Gerupuk.

\section{KESIMPULAN}

Pola musim tanam pada kegiatan budidaya rumput laut memengaruhi tingkat serapan karbon oleh rumput laut, $K$. alvarezii, yang dibudidayakan dengan sistem long-line di perairan Teluk Gerupuk, Nusa Tenggara Barat. Budidaya rumput laut yang dilakukan pada musim tanam yang berbeda (musim produktif dan non-produktif) menghasilkan pola serapan karbon yang berbeda dari setiap siklus tanam. Adanya variabilitas serapan karbon antar musim tanam dipengaruhi oleh perbedaan kondisi lingkungan perairan dan variasi iklim global. Parameter kualitas perairan yang memengaruhi laju serapan karbon oleh rumput laut budidaya terbagi menjadi dua kategori yaitu yang memberikan pengaruh secara langsung dan tidak langsung terhadap laju serapan karbon. Parameter yang berhubungan langsung dengan laju serapan karbon terdiri yaitu DO, tekanan, dan kecerahan perairan; dan yang berhubungan secara tidak langsung yaitu suhu, pH, TDS, dan salinitas, serta kecepatan arus yang berperan sebagai parameter utama yang memengaruhi keempat parameter tersebut. Parameter meteorologi memberikan pengaruh secara tidak langsung terhadap produktivitas budidaya rumput laut.

\section{UCAPAN TERIMA KASIH}

Penulis mengucapkan terima kasih kepada Balai Budidaya Laut Lombok atas bantuan dan kerja sama selama penelitian di lapangan. Kami juga mengucapkan terima kasih kepada Dr. Anang Hari Kristanto, Dr. Idil Ardi, Seme, dan Rusman, M.Si. yang telah membantu kelancaran pengumpulan data lapangan. Penelitian ini merupakan bagian dari penelitian Kajian Dampak Pemanasan Global terhadap Perikanan Budidaya pada Pusat Penelitian dan Pengembangan Perikanan Budidaya Tahun Anggaran 2012.

\section{DAFTAR ACUAN}

Aldrian, E., Karmini, M., \& Budiman. 2011 . Adaptasi dan mitigasi perubahan iklim di Indonesia. Pusat Perubahan Iklim dan Kualitas Udara, Kedeputian Bidang Klimatologi. Badan Meteorologi, Klimatologi, dan Geofisika (BMKG). Jakarta, $178 \mathrm{hlm}$.

Ask, E.I. \& Azanza, R.V. 2002. Advances in cultivation technology of commercial eucheumatoid species: A review with suggestions for future research. Aquaculture, 206: 257277.

Balai Budidaya Laut Lombok [BBL]. 2012. Petunjuk teknis Budidaya rumput laut. Direktorat Jenderal Perikanan Budidaya, Kementerian Kelautan dan Perikanan.

Byrne, K. 1998. Trackling data interpretation question II: photosynthesis. Bio Factsheet No. 25. Curriculum Press. Birmingham, p. 15.

Chakraborty, S. \& Bhattacharya, T. 2012. Nutrient composition of marine benthic algae found in the gulf of kutch coastline, Gujarat, 
India. J. Algal Biomass Utilization, 3(1): 3238.

Chung, I.K., Beardall, J., Mehta, S., Sahoo, D., \& Stojkovic, S. 2011 . Using marine macroalgae for carbon sequestration: critical appraisal. J. Appl. Phycol., 23: 877-886.

Davison, I.R. 1991. Environmental effects on algal photosynthesis: Temperature. J. Phycol., 27: 2-8.

Dawes, C.J. 1981. Marine botany. John Wiley and Sons, Inc. Canada, 628 pp.

Dawson, B. \& Spannagle, M. 2009. The complete guide to climate change. Routledge. New York, 426 pp.

Diniz, G.S., Barbarino, E., Oiano-Neto, J., Pacheco, S., \& Lourenço, S.O. 2011 . Gross chemical profile and calculation of nitrogen-to-protein conversion factors for five tropical seaweeds. American Journal of Plant Sciences, (2): 287-296.

Erlania, Nirmala, K., \& Soelistyowati, D.T. 2013. Penyerapan karbon pada budidaya rumput laut Kappaphycus alvarezii dan Gracilaria gigas di perairan Teluk Gerupuk, Lombok Tengah, Nusa Tenggara Barat. J. Ris. Akuakultur, 8(2): 287-297.

Erlania. 2013. Potensi Budidaya Rumput Laut Kappaphycus alvarezii dan Gracilaria gigas dalam penyerapan karbon. Tesis. Sekolah Pascasarjana. Institut Pertanian Bogor. Bogor, $66 \mathrm{hlm}$.

Food and Agricultural Organzation [FAO]. 2012. The state of world fisheries and aquaculture 2012. FAO Fisheries and Aquaculture Department. Rome, Italy, 209 pp.

Grimsditch, G. \& Chung, I.K. 2012. Yeosu Workshop on "Coastal Blue Carbon" PICES Press, 20(2): 18-20.

Handayani, T. 2011 . Kandungan nutrisi pada rumput laut. Oseana, XXXVI(2): 1-10.

Houghton, J. 2004. Global warming: the complete briefing. Third Edition. Cambridge University Press. New York, 351 pp.

Kaladharan, P., Veena, S., \& Vivekanandan, E. 2009. Carbon sequestration by a few marine algae: Observation and projection. Journal of the Marine Biological Association of India, 51(1): 107-110.

Kementerian Kelautan dan Perikanan [KKP]. 2011. Kelautan dan perikanan dalam angka 2011 . Pusat Data Statistik dan Informasi. Kementerian Kelautan dan Perikanan. Jakarta, $120 \mathrm{hlm}$.

Kementerian Negara Lingkungan Hidup [KLH].
2007. Rencana aksi nasional dalam menghadapi perubahan iklim. Kementerian $\mathrm{Ne}$ gara Lingkungan Hidup. Jakarta, 94 hlm.

Lüning, K. 1990. Seaweed: Their environment, biogeography, and ecophysiology. John Wiley \& Sons, Inc. Canada, 527 pp.

Ministry of Marine Affairs and Fisheries-Japan International Cooperation Agency [MMAFJICA]. 2010. Indonesian Fisheries Book 2010. Co-operation between Ministry of Marine Affair and Fisheries (MMAF) - Japan International Cooperation Agency (JICA). 84 pp.

Marquardt, R., Schubert, H., Varela, D.A., Huovinen, P., Henríquez, L., \& Buschmann, A.H. 2009. Light acclimation strategies of three commercially important red algal species. Aquaculture, 299: 140-148.

Mubarak, H., Ilyas, S., Ismail, W., Wahyuni, I.S., Hartati, S.H., Pratiwi, E., Jangkaru, Z., \& Arifuddin, R. 1990. Petunjuk teknis budidaya rumput laut. Pusat Penelitian dan Pengembangan Perikanan, PHP/KAN/PT/ 13/1990. Jakarta, 93 hlm.

Munõz, J., Pelegrín, Y.F., \& Robledo, D. 2004. Mariculture of Kappaphycus alvarezii (Rhodophyta, Solieriaceae) color strains in tropical waters of Yucatán, México. Aquaculture, 239: 161-177.

Muraoka, D. 2004. Seaweed resources as a source of carbon fixation. Bull. Fish. Res. Agen. Supplement, (1): 59-63.

Neish, I.C. 2005. The eucheuma seaplant handbook. SEAPlantNet Technical Monograph No. 0505-10A. 33 pp.

Nellemann, C., Corcoran, E., Duarte, C.M., Valdés, L., De Young, C., Fonseca, L., Grimsditch, G. (Eds.). 2009. Blue carbon: the role of healthy oceans in binding carbon. $\mathrm{A}$ rapid response assessment. United $\mathrm{Na}-$ tions Environment Programme, GRIDArendal. Birkeland Trykkeri AS, Norway, $78 \mathrm{pp}$.

Radiarta, I.N., Erlania, \& Rusman. 2013. Pengaruh iklim terhadap musim tanam rumput laut, Kappaphycus alvarezii, di Teluk Gerupuk Kabupaten Lombok Tengah, Nusa Tenggara Barat. J. Ris. Akuakultur, 8(3): 453464.

Raikar, S.V., Lima, M., \& Fujita, Y. 2001. Effect of temperatur, salinity and light intensity on the growth of Gracilaria spp. (Gracilariales, Rhodophyta) from Japan, Malaysia, and India. Indian Journal of Marine Sciences, (30): 98-104. 
Ritschard, R.L. 1992. Marine algae as a $\mathrm{CO}_{2}$ sink. Water, Air, and Soil Pollution, (64): 289-303.

Sinha, V.R.P., Fraley, L., \& Chowdhy, B.S. 2001. Carbon dioxide utilization and seaweed production. Proceedings of NETL: First National Conference on Carbon Sequestration 2001.

Stewart, H.L. \& Carpenter, R.C. 2003. The effecs of morphology and water flow on photosynthesis of marine macroalgae. Ecology, 84(1 1): 2,999-3,012.

Sulistijo \& Nontji, A. 1995. Potensi lingkungan laut untuk kegiatan budidaya. Sudradjat et al. (penyunting). Prosiding Temu Usaha Pemasyarakatan Teknologi Keramba Jaring Apung Bagi Budidaya Laut. Jakarta, 12-13 April 1995. Pusat Penelitian dan Pengembangan Perikanan, Badan Litbang
Pertanian bekerja sama dengan Forum Komunikasi Penelitian dan Pengembangan Agribisnis, hlm. 54-68.

Tiensongrusmee, B., Pontjopranowo, S., \& Soedjarwo, I. 1986. Site selection for seaweed farming. FAO, INS/81/008/MANUAL/ 2, April, 1986.

Turtenwald, K. 2013. The Effects of Atmospheric Pressure on Plants. http://www. ehow.com/info_11404255_effects-atmospheric-pressure-plants.html. Diakses tanggal 04 Juni 2013.

Villanueva, R.D., Romero, J.B., Montaño, M.N.E., $\&$ de la Peña, P.O. 2011 . Harvest optimization of four Kappaphycus species from the Philippines. Biomass and Bioenergy, 35: 1,311-1,316. 